\title{
Using glacier area ratio to quantify effects of melt water on runoff
}

\author{
Yiqing Zhang ${ }^{\mathrm{a}, \mathrm{b}}$, Yi Luo ${ }^{\mathrm{a}, \mathrm{b}, \mathrm{c}, *}$, Lin Sun ${ }^{\mathrm{a}}$, Shiyin Liu ${ }^{\mathrm{d}}$, Xi Chen ${ }^{\mathrm{c}}$, Xiaolei Wang ${ }^{\mathrm{a}, \mathrm{b}}$ \\ ${ }^{a}$ Key Laboratory of Ecosystem Network Observation and Modeling, Institute of Geographic Sciences and Natural Resources Research, Chinese Academy of Sciences, Beijing \\ 100101, China \\ ${ }^{\mathrm{b}}$ University of Chinese Academy of Sciences, Beijing 100049, China \\ ${ }^{c}$ Xinjiang Institute of Ecology and Geography, Chinese Academy of Sciences, Urumqi 830011, China \\ ${ }^{\mathrm{d}}$ State Key Laboratory of Cryospheric Sciences, Cold and Arid Regions Environmental and Engineering Research Institute, Chinese Academy of Sciences, Lanzhou 730000, China
}

\section{A R T I C L E I N F O}

\section{Article history:}

Received 29 October 2015

Received in revised form 26 January 2016

Accepted 11 April 2016

Available online 20 April 2016

This manuscript was handled by

Konstantine P. Georgakakos, Editor-in-Chief,

with the assistance of Daqing Yang,

Associate Editor

\section{Keywords:}

Glacier area ratio

Glacier melt

Runoff coefficient

Coefficient of variation of runoff

SWAT

\begin{abstract}
S U M M A R Y
Twenty-four headwater catchments with varying glacier area ratios (GARs) in the Eastern and Central Tian Shan Mountains were simulated by the glacier-enhanced Soil and Water Assessment Tool (SWAT) model from 1961 to 2007. The mean catchment GAR ranges between $0.7 \%$ and $44.8 \%$ with a mean of 8.6\%. Through synthetic analysis of the glacio-hydrological processes simulation results of the catchments, it was found that the GAR is an effective index that can be used to interpret quantitatively the varying influences of glaciers on runoff across catchments. Among the twenty-four catchments, the ratio of glacier melt contribution (RGMC) to runoff varies between $3.5 \%$ and $67.5 \%$ with a mean of $24.0 \%$; the ratio of ice melt contribution (RIMC) between $1.4 \%$ and $35.8 \%$ with a mean of $10.5 \%$; the ratio of ice melt in glacier melt between $33.4 \%$ and $59.1 \%$ with a mean of $43.4 \%$; the runoff coefficient (RC) between 0.24 and 0.90 with a mean of 0.52 ; and the coefficient of variation (CV) of runoff between 0.10 and 0.29 with a mean of 0.18 . Based on synthetic analysis, it was found that (1) power functions fit the relations between RGMC, RIMC, RC, and CV and GAR with high certainty; (2) the CV decreases with increasing GAR while others increase; and (3) these power functions change sensitively with GAR when GAR is less than $10 \%$, implicating that a small change in GAR may cause remarkable changes in RGMC, RIMC, RC, and $\mathrm{CV}$ in the less glacierized catchments.
\end{abstract}

(c) 2016 Published by Elsevier B.V.

\section{Introduction}

Glacier melt usually plays an important role in feeding alpine rivers (Sorg et al., 2012; Lutz et al., 2014). Glacier melt water contribution to runoff has been a research focus in recent years due to its importance in sustaining alpine river flows and its sensitivity to climate change.

A vast amount of studies have been done in last decades to reveal glacial influences on catchment hydrology, attempting to fill the knowledge gap between changes in the cryosphere and river runoff and to rigorously establish the links between glacier retreat and river runoff for glacier-fed rivers, e.g., in Tian Shan Mountains (Unger-Shayesteh et al., 2013). Most recently, studies are focused on differentiating runoff components and detecting the attribution of river runoff change impacted by climate change through hydrological and meteorological data regression analysis or glacio-

\footnotetext{
* Corresponding author at: Institute of Geographic Sciences and Natural Resources Research, Chinese Academy of Sciences, No 11A, Datun Road, Chaoyang District, Beijing 100101, China.

E-mail address: luoyi@igsnrr.ac.cn (Y. Luo).
}

hydrological process simulation-based approach (Prasch et al., 2013; Siderius et al., 2013; Fujita and Sakai, 2014; Duethmann et al., 2015; Mukhopadhyay and Khan, 2015). These studies have achieved understandings of glacier impacts on hydrological processes at both glacier and catchment scales. In reality, catchments differ in physical attributes, such as climate, topography, and glacier coverage, and thus the glacier melt and its contribution to river runoff should exhibit significant differences. Review of the publications indeed reveals that glacier melt contributes remarkably different to runoff from catchment to catchment; even for the same catchment, different studies may obtain different results or even achieve contradictory conclusions due to the different methods adopted (Yang, 1991; Aizen et al., 2000; Kaser et al., 2010). Immerzeel et al. (2010) pointed out that the melt water is extremely important in the Indus and Brahmaputra rivers but only plays a modest role for the Ganges, Yangtze, and Yellow rivers in Asia. Savoskul and Smakhtin (2013) analyzed six major Asian river basins (Indus, Ganges, Brahmaputra, Amu Darya, Syr Darya, and Mekong) and indicated that the glacier melt contribution to river runoff varies significantly. Lutz et al. (2014) indicated that glacier melt contributions to runoff are extremely different among the 
rivers of Indus, Ganges, Brahmaputra, Salween, and Mekong. A metric is needed for understanding quantitatively the glacier impacts on catchment hydrology across catchments.

Looking over the catchments, synthesis based on multicatchments may help to explore hydrological phenomena (Baraer et al., 2015), e.g., the quantitative definition of relationships between variable glacier coverage and alpine watershed hydrologic regimes. Such relationships are crucial for understanding glacio-hydrology geographically. However, the synthetic analysis based on multi-catchments is very limited up to now. Back to three decades, Fountain and Tangborn (1985) performed a synthetic analysis on the glacier effects on stabilizing streamflow variability over fourty-nine catchments, glacierized or non-glacierized, in Washington and Southeast Nevada States of US. They estimated the glacier melt component in runoff by comparing discharges of the glacierized and non-glacierized catchments with similar precipitation and catchment attributes, and developed an empirical function relating proportionality of glacier melt in runoff to glacier area ratio (GAR). Koboltschnig and Schoner (2011) compiled a dataset of glacier melt contribution to runoff for thirty-eight catchments in Austria. The dataset was compiled from diverse sources of glacier melt estimation, e.g., the glacier mass balance observation, simulation of different kind of hydrologic models, and etc. They found a logarithmic fit between the ratios of glacier melt contribution and the GARs. Quite evidently, the researches of glacier melt effects on runoff based on multi-catchments are far from adequacy. In particular, when the glacier melt component is taken into account, the synthetic analysis over multi-catchments is still rarely seen so far. Glacier melt is generally considered as a mixture of supraglacial snowmelt, ice melt, and direct rainfall-runoff on ice surface. The different components are from different origins and occur at distinct temporal scales. The direct rainfall-runoff and snow melt should be considered as fresh input of annual water balance. However, the ice melt releases melt water which was the stored as precipitation of years ago. The glacio-hydrological models of state of the art make it possible to distinguish quantitatively the components of the glacier melt (Luo et al., 2013; Lutz et al., 2014). With differentiation of the glacier melt components simulated by a single model, an insight view of roles of glacier melt in runoff is anticipated not only at catchment scale, but also at regional scale with geographical implications.

The glacierized Tian Shan Mountains develop many rivers and thus are well known as the 'water tower of Central Asia'. The glacier melt contributes considerably to the freshwater supply during summer, which supplies the densely populated arid lowlands in Kyrgyzstan, Kazakhstan, Uzbekistan, Turkmenistan, and Xinjiang/ China (Sorg et al., 2012). Headwater catchments in the Tian Shan Mountains are diverse in climate, topography, area, and glaciations, which are favorable for synthetic studies. This study attempts to establish the relationship between runoff variables and glacier coverage through synthetic analysis over multiple catchments in Tian Shan Mountains, providing quantitative tools for explaining glacier's role in hydrology in a regional sense.

\section{Study site, materials and methods}

\subsection{Regional setting}

The Tian Shan Mountains can be divided into four sub-regions, the Eastern Tian Shan, the Central Tian Shan, the Northern Tian Shan, and the Western Tian Shan (Sorg et al., 2012). The study region covers the Eastern Tian Shan and Central Tian Shan sections. Most part of the study region is located within China, and a small portion of it in Kyrgyzstan (Fig. 1). Due to the effects of topography and atmospheric circulation, this region experiences a temperate continental climate in the southern slope of the Tian Shan Mountains in China; in contrast, a relatively moist climate in the northern slope is observed (Wang et al., 2013). In the region described above, headwater catchments of twenty-four rivers with varying glacier coverage were selected as benchmark catchments for the glacio-hydrological process simulation. Among them, twelve catchments are located in the Eastern Tian Shan, and the other twelve catchments in the Central Tian Shan. The catchment area varies in $165-19,468 \mathrm{~km}^{2}$ with a mean of $4474 \mathrm{~km}^{2}$, and the GAR in $0.8-45.9 \%$ with a mean of $9.4 \%$ in 1960 s and 1970 s. Details in catchment attributes can be referenced to Table 1 .

\subsection{The glacier-enhanced SWAT model}

Soil and Water Assessment Tool (SWAT) is a distributed, process-based hydrologic model and allows a number of different physical processes to be simulated in a watershed with varying soils, land use, and management conditions over long periods of time (Krysanova and Arnold, 2008). SWAT model adapts the concept of Hydrologic Response Units (HRUs) to account for spatial heterogeneities of land covers, soils, and slopes within the subbasin. Land surface hydrological processes are simulated with regard to each HRU, and runoff and sub-surface flows are routed to the outlets of the subbasins through tributaries and then to the outlet of the watershed via the main channels. At present, the SWAT model is capable of simulating rainfall- and snow melt-runoff processes. However, glacier hydrology has not yet been included in the officially released SWAT model.

For applications in alpine river catchments, the hydrologic model has to include the glacio-hydrologic components. It is required that the glacier module can simulate the mass balance and changes in area and volume storage. Meanwhile, differentiation of glacier melt components is a preferable function that helps to understand the glacio-hydrological processes in depth. Luo et al. (2013) proposed a Glacier Hydrologic Response Unit (GHRU) approach for individual glacier simulation and incorporated this algorithm into the SWAT code. In a catchment, each individual glacier is treated as a GHRU which assumes that glacier area may increase or decrease while the HRU area remains unchanged during the simulation. The area of the GHRU is split into two portions, the portion that is bare soil and the portion that is covered by ice. Each GHRU is divided into equal-interval elevation bands. Temperature and precipitation on each band are calculated from their lapse rates, accounting for spatial variability of the climatic factors over the glaciers. Glacier mass balance components are calculated for each band and the total mass balance is computed by summing up over the bands. The GHRU approach at its current state assumes that snow changes into ice directly, without including the intermediate process - firn. The glacier accumulation rate is simply assumed as a ratio of water equivalent of snow over ice. The volume-area scaling relation (Chen and Ohmura, 1990) is used to update the glacier area after the former mass balance year. Among the mass balance components, glacier melt is differentiated into three items, the supraglacial snowmelt, the ice melt, and the direct rainfall-runoff on ice surface. Water yield from glacier and snow melt in the GHRU is routed along with other runoff generated. In addition, Luo et al. (2012) proposed a two-reservoir approach (shallow and deep aquifer) to improve the baseflow simulation of the SWAT model. Following Lutz et al. (2014), the basin-wide runoff calculated by the model is divided into the following four parts: glacier melt, snow melt, rainfall runoff and baseflow. Snow melt consists of the snow melt water released from the snow storage, where sublimation and evaporation are subtracted. Rainfall runoff consists of the surface runoff and lateral flow released from soil water storage generated by rainfall. Baseflow is released from groundwater storage. Runoff from HRUs and GHRUs are routed 


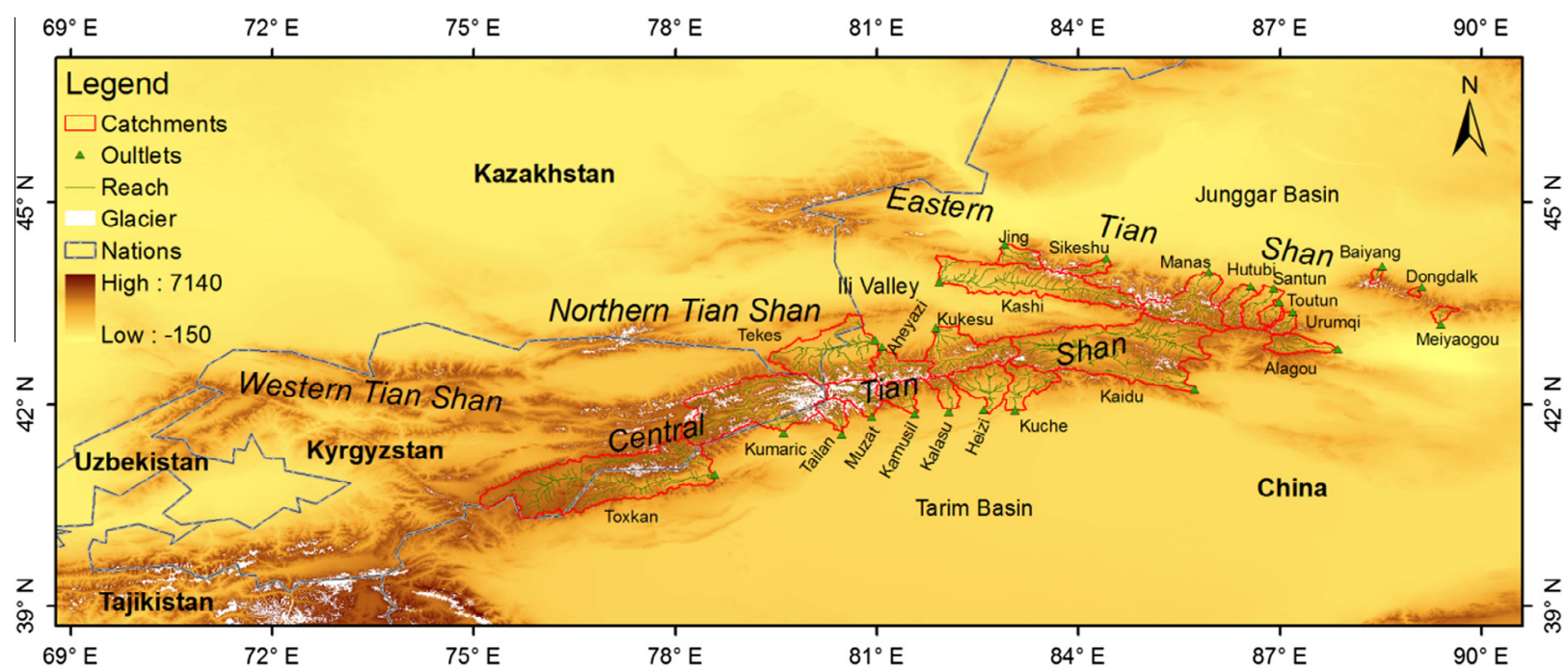

Fig. 1. Location map of the study area: the Tian Shan ranges and the benchmark catchments.

Table 1

Statistical information of the twenty-four benchmark catchments for the simulation of glacio-hydrological processes in the Tian Shan Mountains. asl: above sea level.

\begin{tabular}{|c|c|c|c|c|c|c|c|c|}
\hline \multirow[t]{2}{*}{ Region } & \multirow[t]{2}{*}{ Catchments } & \multirow[t]{2}{*}{ Hydrological stations } & \multirow[t]{2}{*}{ Catchment area $\left(\mathrm{km}^{2}\right)$} & \multicolumn{2}{|l|}{ Glacier } & \multicolumn{3}{|c|}{ Elevation (m asl) } \\
\hline & & & & Area $\left(\mathrm{km}^{2}\right)$ & Initial ratio (\%) & Max. & Min. & Mean \\
\hline \multirow[t]{12}{*}{ Eastern Tian Shan } & Meiyaogou & Meiyaogou & 490 & 10.7 & 2.2 & 4330 & 883 & 2676 \\
\hline & Alagou & Alagou & 1898 & 28.7 & 1.5 & 4436 & 787 & 2927 \\
\hline & Dongdalk & Dongdalk & 165 & 2.2 & 1.3 & 4026 & 1542 & 2889 \\
\hline & Baiyang & Baiyang & 271 & 21.1 & 7.8 & 5377 & 1020 & 2762 \\
\hline & Urumqi & Yingxiongqiao & 923 & 38 & 4.1 & 4450 & 1883 & 3121 \\
\hline & Toutun & Zhicaich & 845 & 20.4 & 2.4 & 4393 & 1435 & 2722 \\
\hline & Santun & Nianpanzh & 1826 & 40.8 & 2.2 & 4507 & 1064 & 2553 \\
\hline & Hutubi & Shimen & 1809 & 72.1 & 4.0 & 5093 & 1252 & 3022 \\
\hline & Manas & Kenswat & 5163 & 608.3 & 11.8 & 5145 & 846 & 3252 \\
\hline & Sikeshu & Jilede & 914 & 105.9 & 11.6 & 4521 & 1067 & 3057 \\
\hline & Jing & Jingheshk & 1409 & 91.1 & 6.5 & 4340 & 685 & 2635 \\
\hline & Kashi & Tuohai & 9541 & 421.6 & 4.4 & 4615 & 798 & 2309 \\
\hline \multirow[t]{12}{*}{ Central Tian Shan } & Kukesu & Kukesu & 5638 & 422.6 & 7.5 & 4795 & 1211 & 2990 \\
\hline & Aheyazi & Aheyazi & 2636 & 548.8 & 20.8 & 5963 & 1737 & 3441 \\
\hline & Tekes & Jiefangdq & 9112 & 555.9 & 6.1 & 5690 & 1638 & 2590 \\
\hline & Kaidu & Dashankou & 18,648 & 423.1 & 2.3 & 4796 & 1097 & 2900 \\
\hline & Kuche & Langan & 2912 & 23.8 & 0.8 & 4488 & 1271 & 2575 \\
\hline & Heizi & Heizi & 3542 & 42.7 & 1.2 & 4802 & 1312 & 2482 \\
\hline & Kalasu & Kalasu & 1309 & 65.6 & 5.0 & 5026 & 1385 & 2721 \\
\hline & Kamusil & Kamuluk & 1843 & 298.7 & 16.2 & 5995 & 1491 & 3268 \\
\hline & Muzat & Pochengz & 2659 & 1219.2 & 45.9 & 6779 & 1869 & 3959 \\
\hline & Tailan & Tailan & 1364 & 444.2 & 32.6 & 7126 & 1568 & 3685 \\
\hline & Kumaric & Xiehela & 12,993 & 2877.7 & 22.1 & 7070 & 1434 & 3732 \\
\hline & Toxkan & Shaliguilk & 19,468 & 811.3 & 4.2 & 5934 & 1888 & 3565 \\
\hline
\end{tabular}

to the outlets of the sub-basins and then to the outlet of the catchment via a channel system with transmission losses deducted. The glacier-enhanced SWAT model has been applied to simulate glaciohydrological processes in several catchments in Tian Shan Mountains (Luo et al., 2013; Gan et al., 2015; Ma et al., 2015; Wang et al., 2015).

\subsection{Data and model setup}

Daily precipitation data were accessed from the Asian Precipitation-Highly Resolved Observational Data Integration Towards Evaluation of Water Resources Data Integration (APHRODITE) at a $0.25^{\circ} \times 0.25^{\circ}$ spatial resolution from 1951 to 2007 . The daily maximum and minimum temperatures were collected from the Global Meteorological Forcing Dataset (GMFD) at a $0.5^{\circ} \times 0.5^{\circ}$ spatial resolution from 1948 to 2008 . The temperature data was downscaled to $0.25^{\circ} \times 0.25^{\circ}$ through a bi-linear interpolation method (Accadia et al., 2003). Six observed stations which are located within or near the benchmark catchments were used to evaluate the APHRODITE precipitation data and GMFD temperature data (Text S1 in Supplementary material). The comparison suggested that grid data matched the observation very well. Digital Elevation Model (DEM) data at a 90-m spatial resolution were extracted from Advanced Spaceborne Thermal Emission and Reflection Radiometer Global Digital Elevation Model (ASTER GDEM). Land use dataset was gathered from the Global Land Cover Product 2009(V2.3) at a 300-m resolution provided by the European Space Agency (ESA) GlobCover Portal. The data were reclassified with the 2001 National Land Cover Data (NLCD) classification system. The soil dataset was obtained from the Harmonized World Soil Database V 1.2 (HWSD) with a 1:1,000,000 scale provided by the International Institute for Applied Systems Analysis (IIASA) and the Food and Agriculture Organization of the United Nations (FAO). All soil mapping units from HWSD were classified based 
on the FAO-90 soil classification system. The glacier dataset was compiled from the First Glacier Inventory in China (GIA-I) and the Second Glacier Inventory in China (GIA-II, Version 1.0) (Guo et al., 2015) and the Tianshan Glaciers Dataset (Aizen et al., 2007). The GIA-I refers to glacier status in 1960s and 1970s, and the GIA-II in 2007-2009. The Tianshan Glaciers Dataset includes two inventories: one for glaciers in 1970s and another in 2000s. The GIA-I and the Tianshan Glaciers Dataset for the 1970s were compiled to initialize the simulation.

The extents of catchments, the delineation of subbasins in each catchment, and the channel systems were derived from the DEM on the platform of ArcSWAT 2005 (Winchell et al., 2007). GHRUs were generated from the glacier maps and the DEM. Every GHRU was divided into elevation bands with equal intervals. Temperature and precipitation in different elevation bands were calculated by monthly lapse rates. The lapse rates of temperature and precipitation were both derived from average monthly values of grid data and ground observation. HRUs were generated from land cover and soil maps on platform of ArcSWAT 2005 also.

The model is run on daily step with temperature and precipitation as the climatic forcing. Hydrologic variables at glacier and catchment scales and at daily, monthly, and annual scales all are outputted for analysis. This study is focused on integrative analysis of the annual results over the multiple catchments.

\section{Results}

\subsection{Model parameterization and evaluation}

Proper model parameterization is crucial for model application. When the glacier-enhanced SWAT model is applied to the alpine catchment, degree-day factors for snow and ice melt and delay time and recession constants for shallow and deep aquifers are sensitive parameters to be calibrated. Variation scopes of these parameters are compiled from the open publications (Gan and Luo, 2013; Luo et al., 2013; Gan et al., 2015; Ma et al., 2015; Wang et al., 2015), providing a reference for the calibration in this study, Table 2.

Calibrating the snow/ice melt factors was performed by adjusting the degree-day factors on 21 June and 21 December (Table 2).

\section{Table 2}

Main sensitive parameters calibrated in the glacier-enhanced SWAT model for the twenty-four catchments in Tian Shan Mountains (Reference ranges were adopted from Liu et al. (1996), Zhang et al. (2006), Cui et al. (2013), Gan and Luo (2013), Luo et al. (2013), Gan et al. (2015), Ma et al. (2015) and Wang et al. (2015).).

\begin{tabular}{|c|c|c|c|c|}
\hline $\begin{array}{l}\text { Variable } \\
\text { name }\end{array}$ & Description & Unit & $\begin{array}{l}\text { Reference } \\
\text { ranges }\end{array}$ & $\begin{array}{l}\text { Calibrated } \\
\text { results }\end{array}$ \\
\hline$\delta_{\mathrm{gw}, \mathrm{sh}}$ & $\begin{array}{l}\text { Delay time of shallow } \\
\text { aquifer }\end{array}$ & days & $15-45$ & $15-35$ \\
\hline$\alpha_{\mathrm{gw}, \mathrm{sh}}$ & $\begin{array}{l}\text { Recession constant of } \\
\text { shallow aquifer }\end{array}$ & - & $0.15-0.4$ & $0.1-0.6$ \\
\hline$\delta_{\text {gw,dep }}$ & $\begin{array}{l}\text { Delay time of the deep } \\
\text { aquifer }\end{array}$ & days & $15-127$ & $100-150$ \\
\hline$\alpha_{\mathrm{gw}, \mathrm{dp}}$ & $\begin{array}{l}\text { Recession constant of } \\
\text { deep aquifer }\end{array}$ & - & $0.02-0.05$ & $0.01-0.08$ \\
\hline SMTMP & $\begin{array}{l}\text { Snow melt base } \\
\text { temperature }\end{array}$ & ${ }^{\circ} \mathrm{C}$ & $0.5-1.5$ & 0.5 \\
\hline SMFMX & $\begin{array}{l}\text { Melt factor for snow on } \\
\text { June } 21\end{array}$ & $\begin{array}{l}\mathrm{mm} \\
{ }^{\circ} \mathrm{C}^{-1} \text { day }^{-1}\end{array}$ & $1-6$ & $2.5-4.5$ \\
\hline SMFMN & $\begin{array}{l}\text { Melt factor for snow on } \\
\text { December } 21\end{array}$ & ${ }^{\mathrm{mm}} \mathrm{C}^{-1}$ day $^{-1}$ & $1-3.5$ & $1.5-3.5$ \\
\hline GMTMP & $\begin{array}{l}\text { Ice melt base } \\
\text { temperature }\end{array}$ & ${ }^{\circ} \mathrm{C}$ & $0.5-1.5$ & 0.5 \\
\hline GMFMX & $\begin{array}{l}\text { Melt factor for ice on } \\
\text { June } 21\end{array}$ & ${ }^{\mathrm{mm}} \mathrm{C}^{-1}$ day $^{-1}$ & $1.0-14.3$ & $2.1-27.3$ \\
\hline GMFMN & $\begin{array}{l}\text { Melt factor for ice on } \\
\text { December } 21\end{array}$ & $\begin{array}{l}\mathrm{mm} \\
{ }^{\circ} \mathrm{C}^{-1} \text { day }^{-1}\end{array}$ & $1-8.0$ & $0.9-10.8$ \\
\hline
\end{tabular}

Previous studies suggested that annual variation of snow melt factors is usually smaller than that of ice melt factors (Zhang et al., 2006; Cui et al., 2013). Liu et al. (1996) determined a melt factor for snow of $3.1 \mathrm{~mm}^{\circ} \mathrm{C}^{-1}$ day $^{-1}$ and for ice between 5.1 and $10.1 \mathrm{~mm}^{\circ} \mathrm{C}^{-1}$ day $^{-1}$ in Urumqi Glacier No. 1 in the source region of the Urumqi River. Cui et al. (2013) reported that melt factor for the East Branch of Glacier No. 1 in 1983-2004 was 1.12-14.3 $\mathrm{mm}^{\circ} \mathrm{C}^{-1}$ day $^{-1}$ and that for the West Branch was 0.98-13.84 $\mathrm{mm}^{\circ} \mathrm{C}^{-1}$ day $^{-1}$, and the factor for snow varied 1.24-2.71 $\mathrm{mm}^{\circ} \mathrm{C}^{-1} \mathrm{day}^{-1}$. Zhang et al. (2006) reported that the melt factors for glaciers in the mountain ranges of northwestern China varied between 2.6 and $13.8 \mathrm{~mm}^{\circ} \mathrm{C}^{-1}$ day $^{-1}$ with a mean of $7.1 \mathrm{~mm}^{\circ} \mathrm{C}^{-1} \mathrm{day}^{-1}$, and snow melt factors ranged from 3.1 to $5.9 \mathrm{~mm}^{\circ} \mathrm{C}^{-1}$ day $^{-1}$ with a mean of $4.1 \mathrm{~mm}^{\circ} \mathrm{C}^{-1}$ day $^{-1}$. The parameters of the glacier volume-area scaling relation were adapted from Liu et al. (2003). Initial values for the parameters in the two-reservoir baseflow approach were from Luo et al. (2012) and were calibrated for each gauge station.

Fundamentally, discharge record series were used as the optimization target for calibration and validation. Additionally, glacier area change based on two phases of the China Glacier Inventory and Tianshan Glaciers Dataset was used to constrain the calibration process, which was done to restrict over parameterization induced by the glacier melt compensation effect.

Monthly runoff data were obtained from the Chinese Hydrological Yearbook, which spans 1961-1989. Data records after 1989 are not publically available. The data series were split into two segments for calibration and validation, respectively. The glacier area change was calculated from the two phases of the glacier inventory for each benchmark catchment. The simulated and observed catchment glacier area changes were plotted against each other, and linear regression analysis was performed to check the coefficient of determination $\left(R^{2}\right)$. The Nash-Sutcliffe efficiency (NSE) (Nash and Sutcliffe, 1970) and percent bias (PBIAS) (Moriasi et al., 2007) are used to evaluate the parameter calibration and validation. NSE and PBIAS are given as:

$N S E=1-\left[\frac{\sum_{i=1}^{n}\left(Q_{i}^{\text {obs }}-Q_{i}^{\text {sim }}\right)^{2}}{\sum_{i=1}^{n}\left(Q_{i}^{\text {obs }}-Q^{\text {mean }}\right)^{2}}\right]$

PBIAS $=\left[\frac{\sum_{i=1}^{n}\left(Q_{i}^{o b s}-Q_{i}^{\text {sim }}\right) \cdot 100}{\sum_{i=1}^{n} Q_{i}^{\text {obs }}}\right]$

where $Q_{i}^{o b s}$ is the $i$ th observation for the streamflow, $Q_{i}^{\text {sim }}$ is the $i$ th simulated value for the streamflow, $Q^{\text {mean }}$ is the mean of the observed data for the streamflow, and $n$ is the total number of observations.

NSE indicates how well the plot of the observed versus simulated data fits the 1:1 line. PBIAS measures the average tendency of the simulated data to be larger or smaller than their observed counterparts. The performance of the streamflow statistics was rated following the extent suggested by Moriasi et al. (2007). Moriasi et al. (2007) also rated the modeling performance as 'very good', 'good', 'satisfactory' or 'unsatisfactory' by using $0.75<N S E \leqslant 1.0, \quad 0.65<N S E \leqslant 0.75, \quad 0.50<N S E \leqslant 0.65, \quad$ or $N S E \leqslant 0.50$, respectively; or by PBIAS $< \pm 10 \%, \pm 10 \% \leqslant$ PBIAS $< \pm 15 \%$, $\pm 15 \% \leqslant$ PBIAS $< \pm 25 \%$, or $P B I A S \geqslant \pm 25 \%$, respectively.

The procedure for parameter calibration is as follows: (1) adjust glacier melt parameters and check the NSE and PBIAS at the calibration stage; (2) run the model for the period from 1961 to 2007 and check the simulated glacier area change against the observed values. If the simulated values match the observed ones well to some extent, then (3) adjust the other parameters to improve the PBIAS; if not, go back to (1) and re-adjust the glacier parameters. The loop may repeat quite a few times until the NSE, PBIAS, and glacier area 
change are acceptable. Calibration is performed manually by trial and error method. During the calibration and validation, the glacier and snow melts, glacier area changes, and streamflow process, water balance, etc. are monitored to maintain rationality of the simulated processes and a rational water balance. Manual calibration is indeed quite difficult. However, having expertise in hydrology and watching the inside processes and intermediate variables in the model make the parameterization 'transparent', efficient, and successful.

Among the twenty-four catchments, NSE varied between 0.58 and 0.94 with a mean of 0.83 (Fig. 2(a)), and the PBIAS between $-13.55 \%$ and $14.24 \%$ with a mean of $2.05 \%$ (Fig. 2(b)). Comparison of the simulated and the observed hydrographs are presented in Fig. S4 in Supplementary material. In addition, the comparison of the simulated and the observed glacier area retreats are depicted in Fig. 3, and the linear regression of the observed and simulated catchment glacier area changes produced an $R^{2}$ of 0.97 (Fig. S5 in Supplementary material). It was concluded that the parameterization of the glacier-enhanced SWAT model for these twenty-four catchments are rated as 'very good' for most cases and 'satisfactory' for a limited cases, following the rating system by Moriasi et al. (2007).

\subsection{The melt water contribution ratios}

The ratios of glacier melt contribution and ice melt contribution to river flow vary significantly among catchments. Among the twenty-four catchments, the ratio of glacier melt contribution (RGMC) to runoff varied between $3.5 \%$ and $67.5 \%$ with a mean of $24.0 \%$; the ratio of ice melt contribution (RIMC) between $1.4 \%$ and $35.8 \%$ with a mean of $10.5 \%$. Details of the contribution ratios for each catchment can be referenced to Table S2 in Supplementary material.

The multi-site simulations of the glacierized catchments make it convenient to analyze the relation between the RGMC or RIMC and the GAR. The mean catchment GAR ranged between $0.7 \%$ and $44.8 \%$ with a mean of $8.6 \%$ in $1961-2007$. The mean ratios and the mean GARs for each catchment are plotted in Fig. 4. It was found that power functions fit the scattered points very well for both the RGMC and RIMC.

Difference between the RGMC and RIMC grows with increasing GAR, and statistically, fraction of ice melt in glacier melt varied between 0.33 and 0.59 with a mean of 0.43 for these twenty-four catchments. Some implications can be inferred from the fractions. As discussed in previous section and literatures (Jansson et al., 2003; Yao et al., 2008), ice is transformed from precipitation. The transformation of precipitation to firn and then consolidation further to ice, and the movement of ice from the accumulation zone to the ablation zone are complicated and lengthy processes. These processes may last for years or even hundred years. The stored precipitation releases as melt water and may play an important role in compensating runoff in dry summers (Braun and Hagg, 2009; Nolin et al., 2010; Sorg et al., 2014). This is the critical component that is widely concerned under climate change. However, other components of glacier melt are related to seasonal precipitation. Their impacts to runoff are the same as that generated over nonglacierized portions of the catchment which are mainly dominated by seasonal precipitation. This may produce a pronounced seasonality in discharge. Therefore, when climate change impact on runoff is discussed for the glacierized catchments, precipitation change induced snow melt and rainfall-runoff components may play a more important role than the temperature-induced ice melt in glacier melt. In the context of application, the RGMC is more widely used than the RIMC because ice melt is difficult to estimate. However, attention should be paid to contribution of supraglacial snowmelt and direct rainfall-runoff on ice surface to runoff for the glacierized catchments. Understanding the shares and roles of the snow melt and rainfall runoff components in glacier melt is conducive to proper interpretation of glacier impacts on hydrologic regimes under climate change.
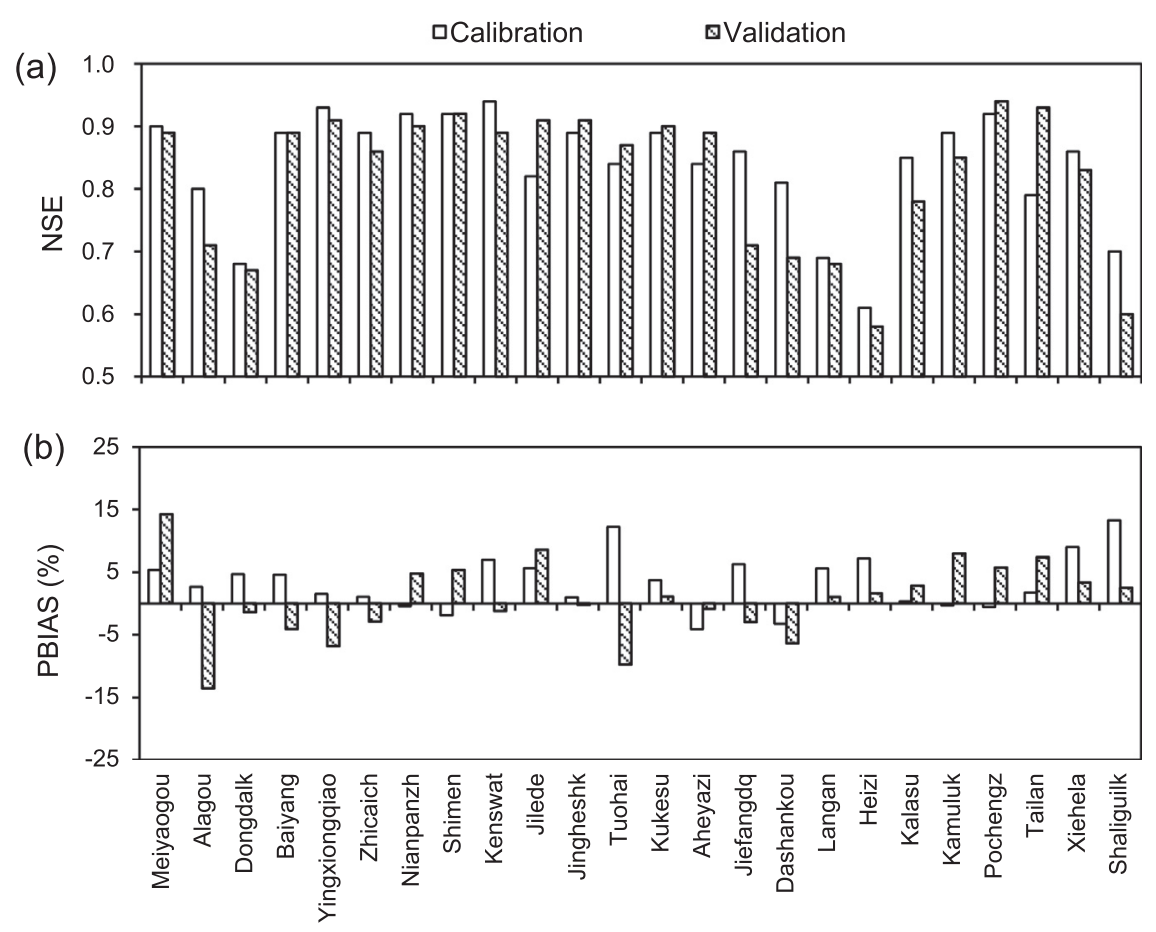

Hydrological stations

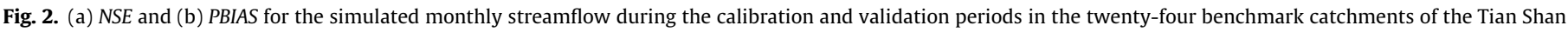
Mountains. 


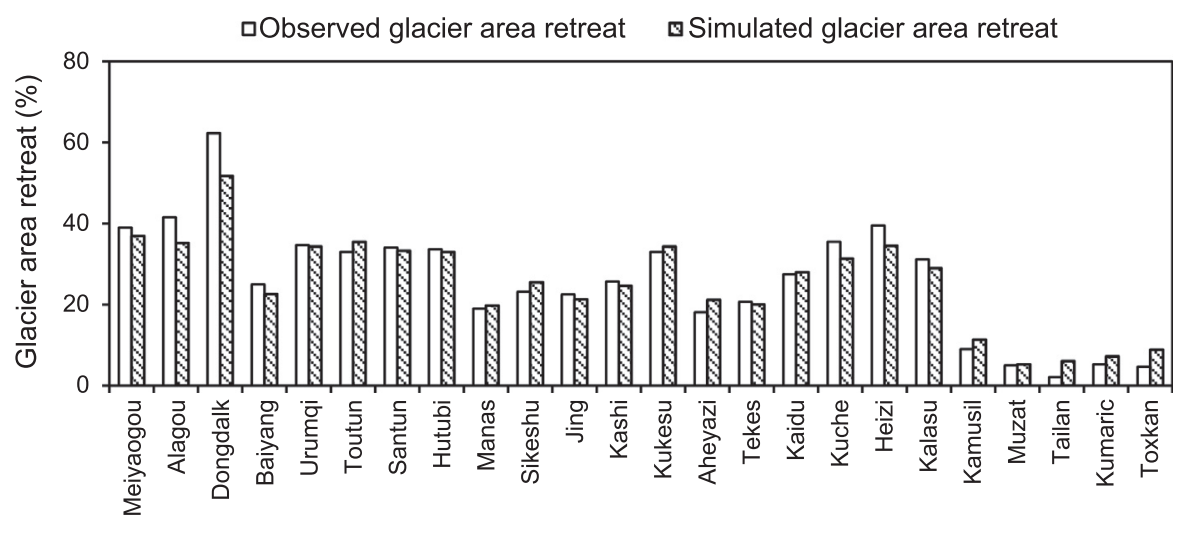

Catchments

Fig. 3. Comparison of the simulated glacier area changes to observations for the twenty-four benchmark catchments in the Tian Mountains.

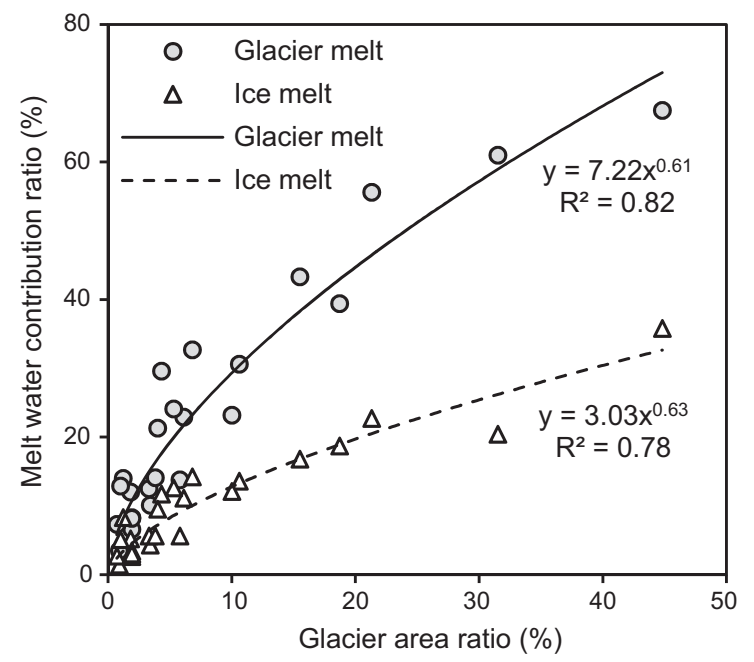

Fig. 4. Plots of the ratios of glacier melt contribution and ice melt contribution against glacier area ratios for the twenty-four catchments in Tian Shan Mountains.

\subsection{Runoff coefficients}

Runoff varied significantly among the catchments, ranging from 75 to $611 \mathrm{~mm}$ with a mean of $290 \mathrm{~mm}$. Percentages of runoff components differed remarkably among the catchments. On average, the baseflow accounted for $28 \%$, and the surface runoff accounted $72 \%$. In the $72 \%$, rainfall runoff, snow melt, and glacier melt shared $32 \%, 16 \%$, and $24 \%$, respectively. The details for each catchment can be referenced to Table S2.

Runoff coefficient $(\mathrm{RC})$ is traditionally defined as a ratio of the runoff to catchment precipitation on annual basis. It is a convenient metric index for estimating river flow volume from the catchment precipitation (Ghiglieri et al., 2014). However, for glacierized catchments, the definition may cause bias when the additional water input from ice melt is neglected.

The mean annual runoff values are plotted against water input for the twenty-four catchments, Fig. 5. When the water input is taken as solely the precipitation, the RC for the twenty-four catchments varied between 0.24 and 0.90 with a mean of 0.52 . A linear regression of runoff to precipitation produced an $R^{2}$ of 0.69 . The RCs for the heavily glacierized catchments were overestimated, particularly for Tailan, Muzat, and Aheyazi. Overestimation of the RCs was due to neglecting the ice melt input into the runoff. When ice melt is added into the water input, the RC varied between 0.24

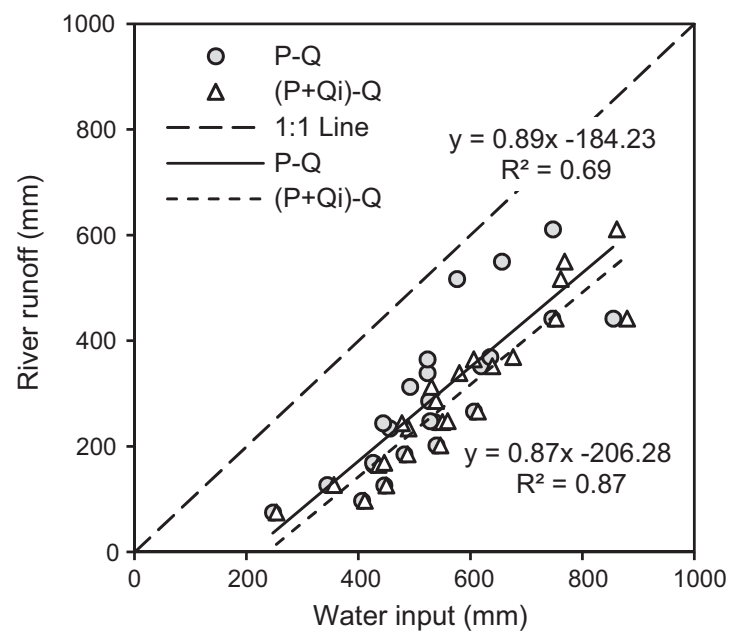

Fig. 5. Regression between runoff and water input (precipitation or precipitation plus ice melt). $P$ is precipitation; $Q_{i}$ is ice melt; $Q$ is river runoff.

and 0.72 with a mean of 0.48 for runoff-precipitation plus ice melt. The linear correlation between runoff and water input was improved profoundly. It was found that a linear regression can account for $87 \%$ of the variations in the precipitation plus ice melt-induced runoff relation. Nevertheless, the traditionally defined RC is more convenient to obtain and easier to use in practice.

Runoff originates primarily from precipitation, falling in a liquid state as rainfall or in a solid state as snow. The solid precipitation is piled up in snowfall season and turns into liquid water again in the snow melt season. This transformation process occurs within the water balance year. Rainfall generates surface runoff almost at daily scale or recharges aquifers and then comes out as baseflow at seasonal scale. Snow may store water over the winter season and release water in the following melt season at seasonal scale (Dickerson-Lange and Mitchell, 2014). However, when snow falls on glacier, the transformation processes get quite complicated. Snow on glaciers may transform into glacier ice and be stored there for a few years or even hundreds of years till it is released as melt water. This transformation process occurs at decadal scale. In a sense of water balance on annual basis, ice melt can be taken as an additional water source.

$\mathrm{RC}$ is a very useful tool to assess the annual runoff volume via the precipitation directly. The RCs, with or without ice melt included, are plotted against the GARs of these catchments, 
Fig. 6. Interestingly, it was found that a power function can fit the relation well, accounting for more than $60 \%$ of the variations of the $\mathrm{RC}$. This can be a reliable reference for selecting RC for a glacierized catchment according to its GAR. For the ungauged catchments in this region, the power functions can be adopted to derive their RCs according to their GARs.

\subsection{Coefficient of variation of runoff}

River runoff varies inter-annually due to inter-annual variability of precipitation and ice melt. The coefficient of variation (CV) of runoff indicates the inter-annual variability, when the larger the $\mathrm{CV}$ is, the stronger the variability of the runoff. Among the twenty-four catchments, the CVs of runoff varied between 0.10 and 0.29 with a mean of 0.18 (Fig. 7).

The CVs of runoff for the twenty-four catchments are plotted against the GARs, Fig. 7. It was found that the variability of runoff decreases with the GAR following a power function curve. The fitted curve can explain more than $60 \%$ of the variation of the CVs. In this study, the maximum GAR is approximately $45 \%$. In a case study of Fountain and Tangborn (1985), the CVs were also plotted against the GARs for the thirty-four catchments in Washington and Southeast Nevada States, US, Fig. 7. They established a fairly complex empirical formula to fit the CV-GAR points and inferred a minimum CV value when the GAR is at $36 \%$. When the GAR exceeds $36 \%$, the CV value turns to increase with the GAR. In that study, a power function curve was fitted to these points and it was found that the curve can account for $51 \%$ of variation of the CVs. With regard to the CV-GAR points for the catchments in Tian Shan Mountains and in the Washington and Southeast Nevada, the role of glaciers in stabilizing runoff variability is affirmed with a certainty more than $50 \%$.

\section{Discussion}

\subsection{Efficiency of GAR as an index in catchment hydrology}

The glacier-enhanced SWAT model simulated the glaciohydrological processes from 1961 to 2007 in twenty-four catchments in Tian Shan Mountains. Based on the annual serials of the hydrological variables, the synthetic analysis achieved beneficial results. The results indicated that RGMC, RIMC, RC, and CV of runoff all are closely related to the catchment GARs. Power function

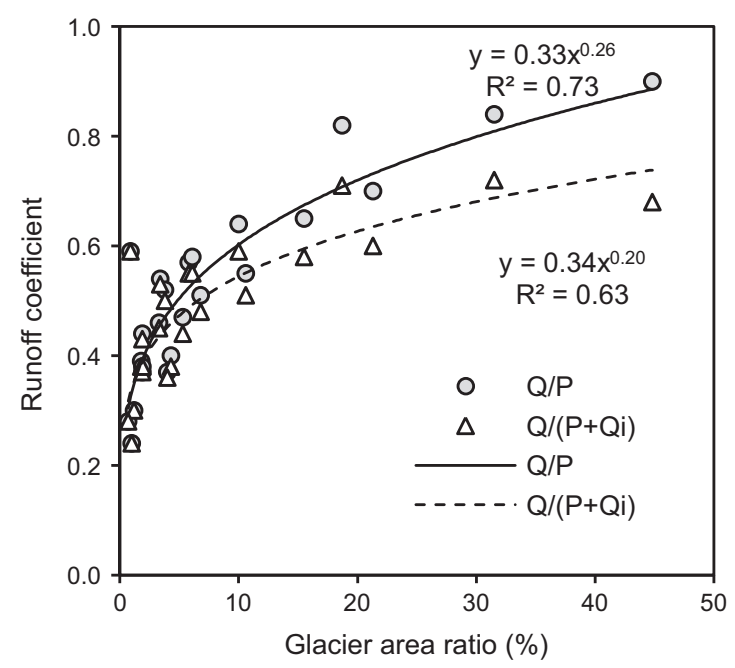

Fig. 6. Plots of runoff coefficients against glacier area ratios for the twenty-four catchments in Tian Shan Mountains.

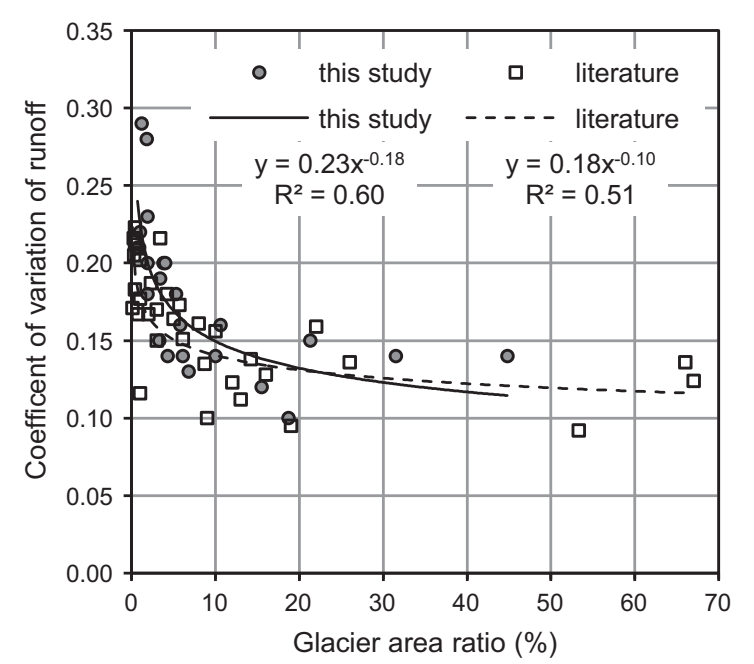

Fig. 7. Coefficients of variation of runoff against glacier area ratios for the twentyfour catchments in Tian Shan Mountains and for the thirty-four glacierized catchments in Washington and Southeast Nevada States of US adopted from literature (Fountain and Tangborn, 1985), and the fitted power function curves.

curves fitted the relations very well, which explained generally $60-82 \%$ of variations among the catchments. The relations derived from multi-catchment synthesis give an overview of the effects of melt water on runoff. GAR has thus been proved an effective index that can interpret quantitatively the role of glaciers in runoff across catchments.

Glacier area can be more easily obtained from glacier inventories or image interpretation at present due to more extensive use of remote sensing images (Cogley, 2010; Pfeffer et al., 2014; Guo et al., 2015). This means that the GAR is also an index that can be easily estimated at catchment scale. Taking into account of data scarcity in alpine catchments, the predictions in the ungauged Basins (PUBs) is a grand challenge (Sivapalan, 2003), especially for the glacierized catchments. Thus, the established empirical functions with GAR as a sole independent variable can be an effective tool in assessing RGMC, RIMC, RC, and CV of runoff, especially for the PUBs. Meanwhile, in a regional issue, these tools are also useful for interpreting spatial heterogeneities of hydrologic regimes of different catchments via spatial variation of GAR values.

\subsection{Functions of glaciers in catchment hydrology}

From the functions established for hydrologic regime variables and GARs, the behavior of glaciers in catchment hydrology can be analytically explained. In the lower range of GAR, RGMC, RIMC, $\mathrm{RC}$, and CV of runoff are sensitive to changes in GAR. A small change in GAR may cause remarkable changes in hydrologic regimes. For example, a small increase in GAR may bring about significant increase in RGMC and RIMC, or a sharp decrease in runoff variability. With a warming climate, alpine glaciers around the world are generally retreating (Barry, 2006; Hirabayashi et al., 2010). Thus, sufficient attention should be paid to these catchments where their GAR is low. The established relationships imply that glaciers are important for catchment hydrology once they are there and no matter how much proportion they occupy the catchment.

As the GAR increases, the role of glacier melt in sustaining the runoff and stabilizing its inter-annual variability is firmly assured. According to the results of this study, the RGMC may exceed $80 \%$ with a GAR of around 50\%, and the RIMC more than $40 \%$. The contribution ratios may be far more than the GAR value stands for. 
The established power functions decrease or increase with the GAR very quickly in low GAR range and the change rates turn to slow down in high GAR range. The transition zone in terms of GAR is with a range of $5-10 \%$, as roughly estimated in this study. This is collaterally supported by previous studies (Fountain and Tangborn, 1985; Hagg et al., 2007; Sorg et al., 2012). The results revealed that the CVs of runoff fall below 0.15 in case the GARs exceed $10 \%$.

\section{Conclusions}

Synthetic analysis of glacio-hydrological processes of twentyfour catchments in Tian Shan Mountains provided an overview of the role of melt water in contributing to and stabilizing the runoff. The results revealed that GAR is an important and effective index, which can be used to explain influences of glaciers on catchment hydrology. Main findings of this study include:

The RGMC, RIMC, RC and CV of runoff are closely related to catchment GARs. Power function curves fitted the relations very well, accounting for the variations in catchments by $60-82 \%$.

The sum of precipitation and ice melt linearly accounts for $87 \%$ of the variations of runoff. The coefficient of the precipitation plus ice melt-induced runoff varied between 0.24 and 0.72 with a mean of 0.48 in the selected twenty-four catchments.

The RGMC, RIMC and RC increase with increasing GARs in catchments, while the CV of runoff decreases. There seems exist a threshold value for the GAR within $5-10 \%$, below which a small change in GAR may cause remarkable change in the coefficients or ratios. Above these thresholds, the coefficients or the ratios change with the GAR much less sensitively.

\section{Acknowledgements}

This study was funded by the National Natural Science Foundation of China (Grant No. 41130641) and Ministry of Science and Technology of China (Grant No. 2010DFA92720; Grant No. 2012BAC19B07).

\section{Appendix A. Supplementary material}

Supplementary data associated with this article can be found, in the online version, at http://dx.doi.org/10.1016/j.jhydrol.2016.04. 026.

\section{References}

Accadia, C., Mariani, S., Casaioli, M., Lavagnini, A., Speranza, A., 2003. Sensitivity of precipitation forecast skill scores to bilinear interpolation and a simple nearestneighbor average method on high-resolution verification grids. Weather Forecast. 18 (5), 918-932.

Aizen, V., Aizen, E., Glazirin, G., Loaiciga, H.A., 2000. Simulation of daily runoff in Central Asian alpine watersheds. J. Hydrol. 238 (1-2), 15-34.

Aizen, V.B., Kuzmichenok, V.A., Surazakov, A.B., Aizen, E.M., 2007. Glacier changes in the Tien Shan as determined from topographic and remotely sensed data. Glob. Planet. Change 56 (3-4), 328-340.

Baraer, M. et al., 2015. Contribution of groundwater to the outflow from ungauged glacierized catchments: a multi-site study in the tropical Cordillera Blanca, Peru. Hydrol. Process. 29 (11), 2561-2581.

Barry, R.G., 2006. The status of research on glaciers and global glacier recession: a review. Prog. Phys. Geogr. 30 (3), 285-306.

Braun, L., Hagg, W., 2009. Present and future impact of snow cover and glaciers on runoff from mountain regions-comparison between Alps and Tien Shan. Assessment of Snow, Glacier and Water Resources in Asia. UNESCO-IHP, IHP/ HWRP, pp. 36-43.

Chen, J., Ohmura, A., 1990. Estimation of Alpine glacier water resources and their change since the 1870s. IAHS Publ. 193, 127-135.

Cogley, J.G., 2010. A more complete version of the World Glacier Inventory. Ann. Glaciol. 50 (53), 32-38.

Cui, Y.H., Ye, B.S., Wang, J., Liu, Y.C., 2013. Influence of degree-day factor variation on the mass balance of Glacier No. 1 at the headwaters of Urumqi River, China. J. Earth Sci.-China 24 (6), 1008-1022.
Dickerson-Lange, S.E., Mitchell, R., 2014. Modeling the effects of climate change projections on streamflow in the Nooksack River basin, Northwest Washington. Hydrol. Process. 28 (20), 5236-5250.

Duethmann, D. et al., 2015. Attribution of streamflow trends in snow and glacier melt-dominated catchments of the Tarim River, Central Asia. Water Resour. Res. 51 (6), 4727-4750.

Fountain, A.G., Tangborn, W.V., 1985. The effect of glaciers on streamflow variations. Water Resour. Res. 21 (4), 579-586.

Fujita, K., Sakai, A., 2014. Modelling runoff from a Himalayan debris-covered glacier. Hydrol. Earth Syst. Sci. 18 (7), 2679-2694.

Gan, R., Luo, Y., 2013. Using the nonlinear aquifer storage-discharge relationship to simulate the base flow of glacier- and snowmelt-dominated basins in northwest China. Hydrol. Earth Syst. Sci. 17 (9), 3577-3586.

Gan, R., Luo, Y., Zuo, Q.T., Sun, L., 2015. Effects of projected climate change on the glacier and runoff generation in the Naryn River Basin, Central Asia. J. Hydrol. 523, 240-251.

Ghiglieri, G., Carletti, A., Pittalis, D., 2014. Runoff coefficient and average yearly natural aquifer recharge assessment by physiography-based indirect methods for the island of Sardinia (Italy) and its NW area (Nurra). J. Hydrol. 519, 17791791.

Guo, W.Q. et al., 2015. The second Chinese glacier inventory: data, methods and results. J. Glaciol. 61 (226), 357-372.

Hagg, W., Braun, L.N., Kuhn, M., Nesgaard, T.I., 2007. Modelling of hydrological response to climate change in glacierized Central Asian catchments. J. Hydrol. $332(1-2), 40-53$.

Hirabayashi, Y., Doll, P., Kanae, S., 2010. Global-scale modeling of glacier mass balances for water resources assessments: glacier mass changes between 1948 and 2006. J. Hydrol. 390 (3-4), 245-256.

Immerzeel, W.W., van Beek, L.P.H., Bierkens, M.F.P., 2010. Climate change will affect the Asian water towers. Science 328 (5984), 1382-1385.

Jansson, P., Hock, R., Schneider, T., 2003. The concept of glacier storage: a review. J. Hydrol. 282 (1-4), 116-129.

Kaser, G., Grosshauser, M., Marzeion, B., 2010. Contribution potential of glaciers to water availability in different climate regimes. Proc. Natl. Acad. Sci. U.S.A. 107 (47), 20223-20227.

Koboltschnig, G.R., Schoner, W., 2011. The relevance of glacier melt in the water cycle of the Alps: the example of Austria. Hydrol. Earth Syst. Sci. 15 (6), 20392048.

Krysanova, V., Arnold, J.G., 2008. Advances in ecohydrological modelling with SWAT - a review. Hydrol. Sci. J. 53 (5), 939-947.

Liu, S.Y., Ding, Y.J., Ye, B.S., Wang, N.L., Xie, Z.C., 1996. Study on the mass balance of the Glacier No. 1 at the headwaters of the Urumqi River using degree-day method. Proceedings of the Fifth Chinese Conference on Glaciology and Geocryology. Gansu Culture Press, Lan zhou, pp. 197-204 (in Chinese).

Liu, S.Y., Sun, W.X., Shen, Y.P., Li, G., 2003. Glacier changes since the Little Ice Age maximum in the western Qilian Shan, northwest China, and consequences of glacier runoff for water supply. J. Glaciol. 49 (164), 117-124.

Luo, Y., Arnold, J., Allen, P., Chen, X., 2012. Baseflow simulation using SWAT model in an inland river basin in Tianshan Mountains, Northwest China. Hydrol. Earth Syst. Sci. 16 (4), 1259-1267.

Luo, Y., Arnold, J., Liu, S.Y., Wang, X.Y., Chen, X., 2013. Inclusion of glacier processes for distributed hydrological modeling at basin scale with application to a watershed in Tianshan Mountains, northwest China. J. Hydrol. 477, 72-85.

Lutz, A.F., Immerzeel, W.W., Shrestha, A.B., Bierkens, M.F.P., 2014. Consistent increase in High Asia's runoff due to increasing glacier melt and precipitation. Nat. Clim. Change 4 (7), 587-592.

Ma, C.K., Sun, L., Liu, S.Y., Shao, M.A., Luo, Y., 2015. Impact of climate change on the streamflow in the glacierized Chu River Basin, Central Asia. J. Arid Land 7 (4), 501-513.

Moriasi, D.N. et al., 2007. Model evaluation guidelines for systematic quantification of accuracy in watershed simulations. Trans. ASABE 50 (3), 885-900.

Mukhopadhyay, B., Khan, A., 2015. A reevaluation of the snowmelt and glacial melt in river flows within Upper Indus Basin and its significance in a changing climate. J. Hydrol. 527, 119-132.

Nash, J.E., Sutcliffe, J.V., 1970. River flow forecasting through conceptual models Part I - a discussion of principles. J. Hydrol. 10 (3), 282-290.

Nolin, A.W., Phillippe, J., Jefferson, A., Lewis, S.L., 2010. Present-day and future contributions of glacier runoff to summertime flows in a Pacific Northwest watershed: Implications for water resources. Water Resour. Res. 46.

Pfeffer, W.T. et al., 2014. The Randolph Glacier Inventory: a globally complete inventory of glaciers. J. Glaciol. 60 (221), 537-552.

Prasch, M., Mauser, W., Weber, M., 2013. Quantifying present and future glacier melt-water contribution to runoff in a central Himalayan river basin. Cryosphere 7 (3), 889-904.

Savoskul, O.S., Smakhtin, V., 2013. Glacier Systems and Seasonal Snow Cover in Six Major Asian River Basins: Hydrological Role under Changing Climate, vol. 150. IWMI.

Siderius, C. et al., 2013. Snowmelt contributions to discharge of the Ganges. Sci. Total Environ. 468, S93-S101.

Sivapalan, M., 2003. Prediction in ungauged basins: a grand challenge for theoretical hydrology. Hydrol. Process. 17 (15), 3163-3170.

Sorg, A., Bolch, T., Stoffel, M., Solomina, O., Beniston, M., 2012. Climate change impacts on glaciers and runoff in Tien Shan (Central Asia). Nat. Clim. Change 2 (10), 725-731.

Sorg, A. et al., 2014. Coping with changing water resources: the case of the Syr Darya river basin in Central Asia. Environ. Sci. Policy 43, 68-77. 
Unger-Shayesteh, K. et al., 2013. What do we know about past changes in the wate cycle of Central Asian headwaters? A review. Glob. Planet. Change 110, 4-25.

Wang, H.J., Chen, Y.N., Chen, Z.S., 2013. Spatial distribution and temporal trends of mean precipitation and extremes in the arid region, northwest of China, during 1960-2010. Hydrol. Process. 27 (12), 1807-1818.

Wang, X.L., Luo, Y., Sun, L., Zhang, Y.Q., 2015. Assessing the effects of precipitation and temperature changes on hydrological processes in a glacier-dominated catchment. Hydrol. Process. 29 (23), 4830-4845.

Winchell, M., Srinivasan, R., Di Luzio, M., Arnold, J., 2007. Arc-SWAT Interface for SWAT2005-User's Guide. USDA Agricultural Research Service and Texas A\&M Blackland Research Center, Temple, Texas.
Yang, Z.N., 1991. Glacier Water Resources in China. Gansu Science and Technology Press, Lanzhou (in Chinese).

Yao, T. et al., 2008. Precipitation record since AD 1600 from ice cores on the central Tibetan Plateau. Clim. Past 4 (3), 175-180.

Zhang, Y., Liu, S.Y., Ding, Y.J., 2006. Spatial variation of degree-day factors on the observed glaciers in Western China. Acta Geogr. Sinica 61 (1), 89-98 (in Chinese). 